\title{
Merekonstruksi Makna Islam sebagai Agama Perdamaian
}

\author{
Sofwan Jannah
}

Islam actually religion of peace which provided by Allah as guidance for life and worshiping Allah, but recently, Islam's face more likely shown as a terrorist, an image that actually far away beyond it's original meaning. Syariat /slam brings guidance to success in this worldly life and eternal life in hereafter, which is known as rahmatan lil 'alamin, it means, Islam, for everyone, even for disbelievers, can live side by side peacefully as long as they respect and uphold each other. Only the power which causes destruction must be taken account as an enemy.

$M$ anusia hidup di muka bumi pada dasarnya untuk mengelola, mengembangkan, dan memakmurkan kehidupan sesama manusia, agar hidupnya sejahtera dan berkehormatan sebagai manusia yang memiliki kelebihan dari makhluk lain, baik dari sisi fisik, rasionalitas, kejiwaan, dan lain sebagainya. Di samping itu, manusia memiliki tugas yang lain yaitu beribadah kepada Allah SWT: Tuhan Yang Maha Pencipta. Oleh karena itu, Allah memberikan bimbingan dan petunjuknya dalam bentuk wahyu melalui Nabi dan Rasulnya agar umat manusia dapat mempelajari dan menjadikan pedoman dalam berkomunikasi dengan Allah, sesama manusia, atau dengan alam sekitarnya.

Khusus dalam interaksi dengan sesama manusia, syari'at Islam memberikan bimbingan agar sukses di dunia dan berbahagia pada saat mempertangungjawabkan aktivitas di dunia kepada Allah SWT di akhirat. Kesuksesan di dunia antara lain ditandai dengan memiliki kesejahteraan dan kedamaian antar keluarga, tétangga, masyarakat, bahkan dalam kehidupan bernegara.
Perbedaan jenis kelamin, suku, dan bangsa pada dasarnya tidak menjadi halangan untuk hidup rukun, karena diciptakan jenis pria, wanita, suku, dan bangsa justru untuk saling mengenal, berkomunikasi, bahkan dapat bekerjasama dalam membangun mahligai rumah tangga, bermitra dalam bisnis, dan lain sebagainya. Perhatikan Firman Allah dalam surat al Hujurat (49): 13 yang artinya:

Hai manusia, sesungguhnya Kami menciptakan kamu dari seorang lakilaki dan seorang perempuan dan menjadikan kamu berbangsa-bangsa dan bersuku-suku supaya kamu saling kenalmengenal...

Di sisi lain perbedaan jenis kelamin, suku, dan bangsa dapat memicu perselisihan, bahkan menjurus pada kriminalitas. Untuk itu dibutuhkan sarana prasarana yang dapat dijadikan upaya untuk mengatasi perselisihan atau perbedaan pendapat itu, yaitu hukum yang mampu memberikan rasa keadilan bagi korban dan memberikan efek jera bagi pelakunya, sehingga kehidupan dalam masyarakat menjadi aman dan terjamin dari rasa takut terhadap lingkungan 
serta mampu beraktivitas sesuai keinginan dan kemampuannya sepanjang tidak merugikan dirinya, orang lain, dan ajaran agamanya.

\section{Islam sebagai pelopor kedamaian}

Islam dilihat dari sisi bahasa berarti damai, sejatera, patuh, dan tunduk oleh karena itu, orang Islam seharusnya mampu menebarkan kedamaian dan kesejahteraan, di samping itu orang Islam akan selalu patuh dan tunduk terhadap tuntunan syari'at Islam. Adapun secara terminologis 'seorang muslim adalah orang yang mampu menebarkan kedamaian untuk dirinya dan orang lain, baik dengan ucapan dan juga perbuatannya. Seorang muslim dituntut agar mampu berkomunikasi yang menyejukkan semua pihak termasuk dengan orang yang tidak seagama, demikian juga aktivitasnya tidak akan menyakiti dan melukai dirinya dan orang lain.' Dengan demikian, dalam berkomunikasi dengan orang lain, harus dicari sisi persamaannya; bukan justru membesar-besarkan perbedaan, sebab kemampuan mencari titik-titik persamaan adalah kunci untuk hidup berdampingan secara rukun dan damai, sebagaimana petunjuk dari Firman Allah dalam Al Qur'an surat Ali Imran (3): 64 yang artinya.

Katakanlah "Hai Ahli Kitab, marilah (berpegang) kepada suatu kalimat (ketetapan) yang tidak ada perselisihan antara kami dan kamu, bahwa tidak kita sembah kecuali Allah dan tidak kita persekutukan Dia dengan sesuatupun dan tidak (pula) sebagian kita menjadikan sebagian yang lain sebagai tuhan selain Allah. Jika mereka berpaling maka katakanlah kepada mereka: "Saksikanlah, bahwa kamiadalah orang-orang yang berserah diri (kepada Allah)".
Apabila dipahami dari ayat di atas, ada tiga pesan yang dapat diambil, yaitu: larangan syirik (menyekutukan Tuhan), menciptakan arbab (semi tuhan; perantara dalam berdo'a atau beribadah), dan memiliki kebanggaan terhadap agama Islam dan kemusliman itu sendiri. Kemusyrikan yang diterjemahkan menyekutukan Tuhan bukan hanya monopoli orang di luar Islam. Akan tetapi, dapat terjadi bagi seorang muslim dapat melakukan kemusyrikan, sehingga mereka terikat dan menggantungkan dirinya tidak hanya kepada Allah; Tuhan Semesta Alam. Demikian pula menciptakan arbab (semi tuhan dan perantara) yaitu orang yang dianggap dekat dengan Tuhan, sehingga doa dan pengampunan umatnya tergantung padanya, sedangkan orang lain jika berdoa dan bertaubat tidak akan dapat diterima.

Kemusyrikan dan arbab pada dasarnya mengakibatkan ketergantungan dan perselisihan, bukan terhadap antaragama saja tetapi juga terhadap sesama pemeluk agama itu sendiri, karena kemusyrikan dan arbab itu sendiri wujudnya beraneka ragam. Betapa banyak sekte-sekte dalam setiap agamayang menjadikan pertikaian dan perselisihan, karena menganggap sektenya yang paling benar sedangkan lainnya dianggap keliru. Itu sebabnya dalam ayat tersebut diakhiri dengan kalimat saksikanlah dalam arti banggalah atau percaya diri sebagai muslim (orang yang islam yang tidak musyrik dan menggantungkan diri pada arbab), karena hanya orang berbangga kepada agamanya tidak akan emosional memaksakan kehendaknya kepada orang lain untuk mengikuti keinginannya, yaitu memeluk agama Islam sebagaimana pesan Al Qur'an surat al Baqarah (2): 256, yang artinya:

Tidak ada paksaan untuk (memasuki) agama (Islam); sesungguhnya telah jelas jalan yang benar daripada jalan 
yang sesat. Karena itu barangsiapa yang ingkar kepada Thaghut dan beriman kepada Allah, maka sesungguhnya ia telah berpegang kepada buhul tali yang amat kuat yang tidak akan putus. Dan Allah Maha Mendengar lagi Maha Mengetahui.

Ayat tersebut menjelaskan bahwa Allah SWT tidak akan pernah memerintahkan umat Islam untuk memaksa orang non muslim menjadi pemeluk Islam. Perhatikan pula satu surat dalam Al Qur'an yang menegaskan bahwa keimanan seseorang itu tidak dapat dicampuradukkan dengan keimanan dari agama lain, perhatikan surat al Kafirun (109): 1-6 yang artinya:

Katakanlah, "Hai orang-orang kafir, kami tidak menyembah apa yang kalian sembah dan kalian pun tidak menyembah apa yang kami sembah. Aku pun tidak menyembah apa yang kalian sembah dan kalian pun tidak menyembah apa yang aku sembah. Bagimulah agamamu dan bagikulah agamaku.

Ungkapan yang disampaikan lewat surat al Kafirun sangat jelas betapa Islam memberikan pengakuan akan adanya perbedaan agama, dan tidak akan saling interfensi dalam beragama, bahkan memerikan toleransi yang cukup tinggi terhadap adanya perbedaan tersebut. Toleransi terhadap perbedaan pendapat dan memeluk agama diberik an sepanjang tidak ada interfensi terhadap akidah atau teologi Islam.

Kearifan syari'at Islam mengharuskan setiap muslim yang mengaku beriman kepada Allah dan hari akhir agar beraktifitas dan berkomunikasi terhadap orang lain siapapun orangnya termasuk non muslim secara baik. Tidak boleh menyakiti hatinya apalagi secara fisik, terutama jika rumahnya berdampingan (bertetangga) sebagaimana
Hadis Rasulullah saw riwayat Bukhari (no. 5559) dari Abi Hurairah r.a.yang artinya:

Barangsiapa beriman kepada Allah dan hari Akhir, maka tidak boleh menyakiti tetangganya, harus memuliakan para tamunya, dan berkomunikasidengan tutur kata yang baik, atau tidak perlu bicara (diam) jika tidak mampu berkomunikasi dengan baik.

Dalam hadis yang lain disebutkan bahwa seorang muslim dapat dikatakan beriman kepadaAllah jika mampu mencintai orang lain (saudaranya) atau tetangganya seperti mencintai dirinya sendiri. sebagaimana Hadis riwayat Muslim (no. 64) dari Anas ibn' Malik r.a.yang terjemahannya:

Belum dianggap beriman seseorang sampaimereka mencintai saudaranya atau tetangganya seperti mencintai dirinya sendiri.

\section{Manusia Ciptaan Allah yang paling Sempurna}

Manusia diciptakan Allah sebagai makhluk yang paling sempurna. Manusia dianugerahi akal untuk berpikir dan hati untuk merasakan, memahami, dan mempersepsi. Ini salah satu kelebihan manusia yang paling utama. Di samping itu, penampilan fisik, manusia diciptakan dengan sebaik-baik bentuk penciptaan: kaki untuk berjalan, tangan untuk memungut, mata untuk melihat, dan lain sebagainya (QS, 65: 4).

Manusia dari aspek penciptaannya sudah memiliki kesempurnaan yang prima, namun tidak dengan sendirinya menjadi mulia, tetapi tergantung pada kemampuan menjalankan tugas dan peran yang telah digariskan Allah. Minimal ada tiga tugas dan peran penting yang harus dilakukan oleh manusia di dunia ini, yaitu: 
Pertama, beribadah kepadaAllah SWT sebagai tugas pokok manusia. Kapan dan di manapun, dalam kapasitas sebagai apa pun suatu aktivitas harus dilakukan dalam rangka ibadah kepada Allah, sebagaimana Firman Allah surat (51): 56 yang artinya.

"Dan Aku tidak menciptakan manusia kecualisupaya mereka menyembah-Ku."

Kedua, bertugas sebagai khalifah, yaitu bahwa setiap nilai-nilai dan ketentuan yang berasal dari Allah SWT harus ditegakkan dalam kehidupan di dunia. Untuk itu, manusia diberi peran oleh Allah SWT sebagai khalifah (wakil)-Nya di muka bumi, dalam rangka menegakkan syariat-syariatNya, sebagaimana Firman Allah surat al Baqarah (2): 30 yang artinya:

"Ingatlah ketika Tuhanmu berfirman kepada para Malaikat "Sesungguhnya Aku hendak menjadikan seorang khalifah di muka bumi."

Untuk mengaplikasikan fungsi khalifah, manusia harus menegakkan nilai-nilai kebenaran, keadilan dan menebarkan kemaslahatan. Tanpa ketiganya tidak mungkin tatanan kehidupan umat manusia dapat diwujudkan, "karena ketiganya menjadi persyaratan utama bagi manusia untuk menjalankan fungsi khalifah pada dirinya (QS Shad (38): 26, al Maidah (5): 8, dan an Nisa' (4): 58).

Ketiga, membangun peradaban agar kehidupan dan martabat manusia tidak sama dengan binatang, sebagaimana Firman Allah surat Huud (11): 61 yang artinya:

"... Dia telah menciptakan kamu dari bumi (tanah) dan menjadikan pemakmurnya..."

Untuk itu sudah tersedia lima fondasi yang harus diwujudkan:

1. nilai-nilai Islam yang datang dari Allah 2. nyawa dan jiwa manusia merupakan anugrah yang harus dijaga dan dipertahankan

3. akal yang menjadi modal besar untuk berpikir dan berkreasi

4. harta benda yang halal dan baik

5. keturunan (nasab) manusia, karena akan berpengaruh pada kehormatan manusia yang berakhlak dan berkepribadian.

Kelima fondasi tersebut untuk membangun peradaban agar martabat manusia tidak menjadi lebih rendah dari binatang bahkan, lebih buruk lagi, dan di akhirat kelak dimasukkan ke dalam neraka dengan segala kesengsaraannya, sebagai akibat dari keengganan dan kelalaian memberdayakan segala potensi dan kapasitas manusiawi yang dimiliki sebagaimana ditegaskan dalam Al Quran surat al A'raf (7): 179 dan surat at Tin (95): 4-6 yang artinya:

Dan sesungguhnya Kamijadikan untuk isi neraka Jahanam kebanyakan dari jin dan manusia, mereka mempunyai hati, tetapi tidak dipergunakannya untuk memahami (ayat-ayat Allah) dan mereka mempunyai mata (tetapi) tidak dipergunakannya untuk melihat (tandatanda kekuasaan Allah), dan mereka mempunyai telinga (tetapi) tidak dipergunakannya untuk mendengar (ayat-ayat Allah). Mereka itu sebagai binatang ternak, bahkan mereka lebih sesat lagi. Mereka itulah orang-orang yang lalai.

Kemudian Kami kembalikan dia ke tempat yang serendah-rendahnya (neraka), kecuali orang-orang yang beriman dan mengerjakan amal saleh; maka bagi mereka pahala yang tiada putus-putusnya.

Nilai keislaman yang datang dari Allah harus dipelihara di atas segalanya, bila perlu 
harus dipertahankan meskipun harus mengorbankan waktu, harta, bahkan nyawa sekalipun. Seorang muslim dapat menghabiskan sebagian waktunya untuk beribadah dan mensosialisasikan kebenaran ajaran Islam kepada seluruh umat manusia. Apabila memiliki harta kekayaan setiap muslim diarahkan membelanjakan hartanya untuk membela agama, berpartisipasi secara aktip mengentaskan berbagai bentuk kemiskinan, kefakiran, dan kebodohan dalam bentuk menunaikan zakat, infak, sadakah, bahkan wasiat dan wakaf untuk kegiatan pendidikan dan lain sebagainya.

Itu sebabnya dalam setiap transaksi diperlukan alat bulti tertulis terutama terhadap transaksi kredit atau yang memiliki nilai yang relatip berharga, bahkan diperlukan dua orang saksi laki-laki yang adil dan jujur. Anjuran penulisan bukti tertulis itu ditekankan betul, agar tidak terjadi fitnah di kemudian hari, contoh kongkrit antara lain terhadap utang piutang memerlukan perjanjian tertulis, sedangkan transaksi tanah diperlukan akte jual beli dan sertifikat, dan lain sebagainya sebagaimana Firman Allah SWT dalam surat al Baqarah (2): 282 yang artinya.

Haiorang-orang yang beriman, apabila kamu bermu'amalah tidak secara tunai untuk waktu yang ditentukan, hendaklah kamu menuliskannya. Dan hendaklah seorany penulis di antara kamu menuliskanriya dengan benar. Dan janganlah penulis enggan menuliskannya sebagaimana Allah telah mengajarkannya, maka hendaklah ia menulis, dan hendaklah orang yang berhutang itu mengimlakkan (apa yang akan ditulis itu), dan hendaklah ia bertakwa kepada Allah Tuhannya, dan janganlah ia mengurangi sedikitpun daripada hutangnya. Jika yang berhutang itu orang yang lemah akalnya atau lemah (keadaannya) atau dia sendiri tidak mampu mengimlakkan, maka hendaklah walinya mengimlakkan dengan jujur. Dan persaksikanlah dengan dua orang saksi dari orang-orang lelaki diantaramu). Jika tak ada dua orang lelaki, maka (boleh) seorang lelaki dan dua orang perempuan dari saksi-saksi yang kamu ridhai, supaya jika seorang lupa maka seorang lagi mengingatkannya. Janganlah saksisaksi itu enggan (memberiketerangan) apabila mereka dipanggil; dan janganlah kamu jemu menulis hutang itu, baik kecil maupun besar sampai batas waktu membayarnya. Yang demikian itu, lebih adil di sisi Allah dan lebih dapat menguatkan persaksian dan lebih dekat kepada tidak (menimbulkan) keraguanmu, (Tulislah mu'amalahmu itu), kecuali jika mu'amalah itu perdagangan tunai yang kamu jalankan di antara kamu, maka tak ada dosa bagi kamu, (iika) kamu tidak menulisnya. Dan persaksikanlah apabila kamu berjual beli; dan janganlah penulis dan saksi saling sulit-menyulitkan. Jika kamu lakukan (yang demikian), maka sesungguhnya hal itu adalah suatu kefasikan pada dirimu. Dan bertakwalah kepada Allah; Allah mengajarmu; dan Allah Maha Mengetahui segala sesuatu.

Nyawa setiap orang sangat berharga di sisiAllah, itu sebabnya pelaku pembunuhan meskipun dilakukan tanpa sengaja tetap dikenai sangsi diat (ganti rugi), apalagi jika dilakukan dengan sengaja, maka hukuman yang harus dijalani adalah hukuman yang setimpal atau sebanding dengan perbuatannya. Hal ini dilakukan agar nyawa setiap orang harus dijamin dan dijaga, sedangkan orang yang terbersit dalam hatinya untuk membunuh dapat menyadari 
sebelum berbuat, karena melakukan pembunuhan pada orang lain sama saja dengan melakukan bunuh diri. Perhatikan filosofi yang terkandung dalam Al Qur'an surat al Baqarah (2): 179 yang artinya.

Dan dalam qishaash itu ada (jaminan kelangsungan) hidup bagimu, hai orang-orang yang berakal, supaya kamu bertakwa.

Realitas di lapangan hukum Islam dalam bentuk diat (ganti rugi terhadap hilangnya nyawa manusia) telah diakui eksistensinya di dunia internasional, seperti yang terjadi dalam kasus pembajakan yang berakibat jatuhnya pesawat "Pan Am" di Lockerbi dengan tertuduh pelakunya dua orang warga Libya, kemudian setelah libya mau memberikan uang duka kepada keluarga korban, maka Amerika dapat memberikan kelonggaran dan mencabut embargo kepada Libia.

Aktivitas teroris dalam hukum Islam belum dielaborasi secara serius. Keadaan ini dapat terjadi karena pemahaman teks $\mathrm{Al}$ Qur'an tentang jarimah tersebut masih menggunakan penafsiran model figh lama, padahal jika diamati secara baik maka ayat hirobah sangat tepat apabila diterapkan untuk pidana teror, hal ini karena aktivitas teror akan berakibat banyak korban, mulai dari rasa was-was, ketakutan, korban harta, bahkan sampai menghilangkan nyawa orang lain. Oleh karena itu, prilaku yang dapat dikategorikan sebagai aktivitas teroris, dapat dikenai hukuman hirobah, yaitu sebagaimana Firman Allah surat al Maidah (5): 33 yang artinya.

Sesungguhnya pembalasan terhadap orang-orang yang memerangi Allah dan Rasul-Nya dan membuat kerusakan di muka bumi, hanyalah mereka dibunuh atau disalib, atau dipotong tangan dan kaki mereka dengan bertimbal balik, atau dibuang dari negeri (tempat kediamannya). Yang demikian itu (sebagai) suatu penghinaan untuk mereka didunia, dan di akhirat mereka beroleh siksaan yang besar,

Seseorang yang melakukan aktivitas teror tidak dapat lagi dapat mengatasnamakan jihad, karena memeng perbuatannya setara dengan memerangi Allah dan Rasulullah, sehingga jika sampai menghilangkan nyawa, tidak hanya dihukum mati, tetapi diikuti dengan disalib. Dengan demikian, sangat wajar jika ancaman hukumannya adalah mati dengan disalib menandakan bahwa para pelaku teror mati dalam keadaan memerangi Allah dan Rasulnya sehingga dapat pula diterjemahkan mati secara tidak Islam.

Ancaman hukuman yang sangat berat tersebut diharapkan dapat mengurangi aktivitas teroris yang mengatasnamakan jihad, sementara perbuatannya justru menyimpang dari syari'at, sebagai bukti antara lain dana yang diperoleh untuk bom bali adalah dari hasil perampokan.

Seorang yang mengaku muslim akan selalu menjaga dan memelihara akalnya untuk berpikir, berkreasi, dan kegiatan yang bermanfaat. Itu sebabnya dalam syari'at Islam haram meminum minuman keras, narkotika, dan obat-obatan yang merusak akal, bahkan pelakunya dianggap berbuat kriminal yang dapat dipidana, dengan sanksi dihukum dera sebanyak 40 kali.

Harta kekayaan yang dimiliki sepatutnya dijaga keutuhannya, bahkan harus dikembangkan agar pemanfaatannya dapat dilakukan secara optimal untuk kesejahteraan dirinya, keluarga, tetangga, dan orang di sekitarnya. Itu sebabnya keamanan dan ketenangan dalam berusaha harus diciptakan. Sebaliknya para pengganggu harta kekayaan baik pencuri, pencopet, penjegal, dan perampok dapat dijatuhi hukuman yang cukup mengerikan (potong 
tangan) sehingga perolehan dan menikmati harta hasil pencurian berapa pun banyaknya tidak sebanding jika dibanding-kan dengan tangannya yang harus dipotong. Tentu hal ini akan menjadikan mereka berpikir 100 kali lipat untuk melakukan pencurian.

Hukum potong tangan secara sepintas cukup mengerikan dan sadis, sehingga timbul pemikiran apabila diberlakukan di Indonesia, maka dalam beberapa bulan saja pendududk Indonesia akan banyak yang terpotong tangannya. Pemikiran yang demikian terlalu naïf, karena dalam sejarah pemberlakuan hukum Islam, pencuri yang dipotong tangannya hanya 6 orang dalam kurun waktu 400 tahun (Muhammad Qutb. 1994: 252)

Kemungkinan terjadi perselisihan harta kekayaan disebabkan pembagian harta wạrisan yang tidak imbang sesuai dengan rasa keadilan berdasarkan fungsi anggota keluarga. Itu sebabnya dalam syari'at Islam mengatur pembagian harta waris secara detail dalam Al Qur'an. Mengapa pada umumnya perolehan laki-laki lebih besar dari perolehan perempuan. Alasan yang mendasar karena di samping laki-laki adalah orang yang bertanggungjawab untuk pencarj nafkah, juga laki-laki dimungkinkan untuk melakukan poligami, sehingga perolehan harta warisnya pun lebih besar. Adapun wanita tidak dimungkinkan untuk poliandri, karena kehormatan dian kepastian nasab seseorang sangat sulit diperoleh dari wanita yang poliandri.

Demikian pula nasab yang akan menjadi penerus generasi yang akan datang, sangat perlu dijaga kehormatannya, maka perbuatan zina yang akan merusak nasab, dan martabat manusia yang berkehormatan harus dicegah seoptimal mungkin dan pelakunya dapat dipidana dengan dera 100 kali dan eksekusinya disaksikan orang banyak. Dengan demikian, pelakunya dapat berfikir 1000 kali karena perbuatannya akan berakibat mempermalukan dirinya sendiri sepanjang hidupnya.

Akibat perbuatan zina dapat berakibat kehamilan yang dapat membuahkan keturunan, mungkin dapat ditutupi dengan formalitas perkawinan atau pindah tempat tinggal. Akan tetapi, dapatkah menutupinya dari pertanyaan anaknya jika kelak sudah dewasa, mengapa terlahir dengan jarak yang sangat dekat dengan saat akad nikah orang tuanya? Dapatkah kedua orang tuanya mendidik anaknya agar mampu menjaga moralitas, sementara anaknya mengetahui orang tuanya pernah melakukan aib. Namun demikian, eksekusi terhadap hukuman zina tidak pernah dapat dilakukan apabila menggunakan syarat empat orang saksi laki (sebagai alat bukti) yang mengetahui dengan detail perbuatan zina yang terjadi. Adapun yang pernah terjadi pada masa Umar ibn Khattab adalah karena pengaduan seorang wanita yang diperkosa, dan kemudian diakui oleh pelaku zina.

Di samping itu, eksekusi hukum pidana Islam dapat diberlakukan, jika putusan hakim sudah memiliki kekuatan sesuai prinsip yang harus ada, yaitu: pertama: hukuman hudud tidak boleh diberlakukan selama masih ada syubhat (keraguan), baik karena kurang alat bukti, syubhat milik, dan lain sebagainya. kedua: keliru dalam memaafkan jauh lebih baik daripada keliru menghukum. Oleh karena itu, hanya orang yang diyakini secara pasti bersalah yang dapat dikenai sanksi hukuman, sebagaimana hadis Rasulullah saw riwayat Tirmizi dari Aisyah r.a. yang artinya.

Hindarkan hukuman (hudud) dari muslimin sedapat mungkin, maka jika kamu temukan jalan keluar bagi muslim, berikanlah jalan keluarnya (sehingga ia lolos dari hukuman). Sesungguhnya bila imam salah dalam 
memaafkan, lebih baik daripada salah dalam menghukum.

Atas dasar adanya punishment terhadap para pelaku kriminal, akan memberikan rasa keadilan dan mendidik masyarakat, sehingga diharapkan tidak terjadi adanya rasa iri dan gangguan keamanan, sehingga kehidupan dalam masyarakat terjamin, dan hidup harmoni dalam kedamaian dan ketentraman.

\section{Dunia sebagai Tempat untuk Mengaktualisasikan diri}

Manusia hidup di dunia diilustrasikan sebagai petani dengan ladangnya, tanah bukan merupakan tujuan, tetapi sebagai sarana yang digunakan untuk mengamankan diri dan untuk memperoleh hasil dari pertanian untuk mencapai kebahagiaan. Dapat pula ibarat antara pebisnis dengan pasar tempat usaha untuk memperoleh keuntungan yang dapat dijadikan sarana mencapai kebahagiaan hidup. Oleh karena itu, dunia dapat dipandang sebagai sawah bagi masa depan (akhirat), karena itu tidak selayaknya semua tanahnya dijadikan tempat tinggal yang permanen.

Namun demikian, setiap manusia yang secara kodrat memiliki akal, naluri, kata hati, dan hawa nafsu mampu mengendalikan diri untuk tetap dalam bimbingan Allah. Dalam aktivitasnya dapat saja terjadi hawa nafsu mendominasi akalnya, sehingga manusia yang seharusnya berbuat arif, justru mengikuti hawa nafsunya sehingga perbuatannya merugikan orang lain. Allah sudah mengetahui keadaan yang akan terjadi pada manusia, sehingga diperlukan aturan atau hukum yang dapat dijadikan pedoman agar umat manusia tetap dapat hidup dalam koridor sebagai makhluk yang berkehormatan, maka Allah pun memberikan aturan dan petunjuk yang diperlukan itu. Perhatikan Firman Allah dalam surat an Nisa' (4): 61 yang artinya.

Apabila dikatakan kepada mereka: "Marilah kamu (tunduk) kepada hukum yang Allah telah turunkan dan kepada hukum Rasul", niscaya kamu lihat orang-orang munafik menghalangi (manusia) dengan sekuat-kuatnya dari (mendekati) kamu.

Dari ayat tersebut, dipahami bahwa tidak semua orang mampu mengikuti aturan hukum yang disediakan Allah, terutama orang munafik dan orang-orang yang mempertahankan kebiasaan yang telah dilakukan nenek moyang mereka, meskipun kebiasaan itu tidak masuk akal dan bertentangan dengan syari'at Islam, sebagaimana surat al Maidah (5): 104

Apabila dikatakan kepada mereka: "Marilah mengikuti apa yang diturunkan Allah dan mengikuti Rasul". Mereka menjawab: "Cukuplah untuk kami apa yang kami dapati bapak-bapak kami mengerjakannya". Dan apakah mereka akan mengikuti juga nenek moyang mereka walaupun nenek moyang mereka itu tidak mengetahui apa-apa dan tidak (pula) mendapat petunjuk?

\section{Kerukunan Umat Beragama}

Rasulullah saw pernah memberikan kesempatan kepada umat Nasrani dan Yahudi hidup berdampingan secara damai di kota Madinah, selanjutnya dibuat suatu perjanjian tertulis yang dikenal dengan Misak Madinah (Piagam Madinah) yang isinya memberikan toleransi dan kesempatan untuk bekerja sama membangun dan mempertahankan kota Madinah dari ancaman musuh dari luar. Piagam Madinah tersebut dikenal sebagai aturan tertulis pertama yang spektakuler, karena pada masa itu yang mendominasi kehidupan 
masyarakat internasional adalah hukum Romawi dan Persia; dan tidak mengenal adanya kerukunan hidup beragama. Oleh karena itu, piagam Madinah dikenal pula sebagai Undang-Undang Dasar Negara yang sangat moderat pada masanya

Syari'at Islam hadir di muka bumi dalam rangka rahmatan lil 'alamin artinya akan memberi kesejukan kepada siapa pun termasuk bagi masyarakat non muslim dengan syarat mereka mau berdampingan dan hidup rukun, damai, dan saling menghargai. Akan tetapi, jika aktivitas mereka merongrong keharmonisan, maka aktivitasnya perlu diluruskan kembali, agar rasa aman tetap dapat dinikmati masyarakat. Perhatikan bagaimana upaya yang diajarkan oleh Al Qur'an dalam menghadap para pemberontak yang seiman, maka upaya preventif yang harus dilakukan, sehingga jika sudah menyerah perlakuannya pun harus dengan dilakukan secara manusiawi.

Kehidupan umat Islam, Yahudi, dan Nasroni di Madinah dalam keadaan rukun dan damai relatif lama, hanya sangat disayangkan orang Yahudi dan Nasrani yang diberi kepercayaan untuk hidup bersama dengan kaum muslimin secara damai dan sejahtera, kemudian menghianati dan bekerjasama dengan musuh dari luar untuk berbuat licik dan berniat menelikung dari belakang. Setelah diketa'uui prilakunya yang akan merugikan komunitas kaum muslimin, maka orang Yahudi dan Nasrani diusir dari kota Madinah, oleh karena itu, sampai sekarang kota Madinah dan Mekah steril dari umat non muslim.

\section{Penutup}

Meskipun setiap muslim sudah diberikan petunjuk untuk berprilaku yang mampu menyejukkan suasana hidup, sejahtera dan penuh kedamaian, tetapi manusia dapat saja memperturutkan hawa nafsunya, sehingga mereka menjurus pada perbuatan yang nista, kriminal, bahkan dapat saja menjadi provokator yang membuahkan perbuatan teror. Oleh karena itu, Syari'at Islam memberikan aturan hukum pidana terhadap para terpidana yang dengan sengaja melanggar hukum dan diyakini secara nyata sebagai pelakunya, sebab bagi tersangka pelaku yang kurang memenuhi syarat, atau kurang memiliki alat bukti tidak boleh dikenai hukuman. Hal ini karena perinsip eksekusi dalam hukum Islam adalah tidak boleh diterapkan hukuman "hudud" jika terdapat syubhat (keraguan) dan perinsip "keliru memaafkan lebih baik daripada keliru dalam menghukum.

\section{Daftar Pustaka}

Audah, Abd al Qodir. Tanpa tahun. At Tasyri' al Jinayat Islami, Muqoronah bi al Qonun al Wadh'iy.

Bukhori, Muhammad bin ismail, Al. 1952. Shahih-al Bukhori. III. Mesir: Dar wa Mathba'ah asy-Syu'aib.

Departemen Agama RI.1990, Yayasan Penyelenggara Penterjemah Al-Qur'an. AlQur'an dan terjemahnya. Jakarta: CV. Kathoda.

Muslim bin Hajjaj al-Qusyairi, Tanpa tahun, Shohih Muslim bi Syarh Nawawi. V. Mesir: Mathba'ah al- Misyriyah.

Qutb, Muhammad. 1964. Islam The Misunderstood Religion, Kuwait: Darul Bayan Bookshop.

Qosimi. Dzafir al, Tanpa Tahun, Nizam al Hukmi fi asy Syariah wa al Tariqah al Islami. 